
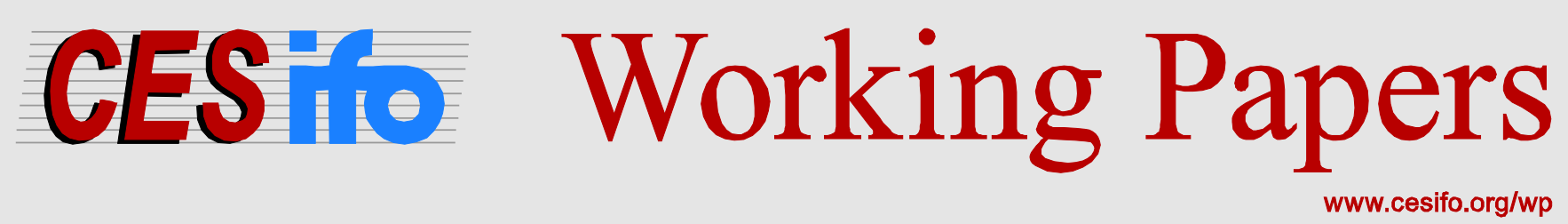

\title{
Using Bankruptcy to Reduce Foreclosures: Does Strip-down of Mortgages Affect the Supply of Mortgage Credit?
}

\author{
Wenli Li \\ Ishani Tewari \\ Michelle J. White
}

CESIFO WORKING PAPER NO. 4722

CATEGORY 1: PubliC FinANCE

MARCH 2014

\footnotetext{
An electronic version of the paper may be downloaded

- from the SSRN website:

- from the RePEc website:

- from the CESifo website:

wWw.SSRN.com

www.RePEc.org

www.CESifo-group.org/wp
}

\section{CESifo}




\title{
Using Bankruptcy to Reduce Foreclosures: Does Strip-down of Mortgages Affect the Supply of Mortgage Credit?
}

\begin{abstract}
We assess the credit market impact of allowing mortgage "strip-down" as a foreclosureprevention measure, where strip-down reduces the principal of underwater residential mortgages to the current market value of the property for homeowners in Chapter 13 bankruptcy. Our identification is provided by a series of U.S. court decisions that introduced strip-down in parts of the U.S. and a Supreme Court ruling that abolished it. We find that the Supreme Court decision led to a small, short-term reduction in mortgage interest rates and a small, short-term increase in mortgage approval rates, but no long-term effects, and the circuit court decisions did not consistently affect mortgage terms. These results suggest that stripdown would be an effective foreclosure-prevention program, because it would have only small and transient effects on the supply of mortgage loans.
\end{abstract}

JEL-Code: K350.

Keywords: mortgage, foreclosure, credit market, credit supply, strip-down.

Wenli $\mathrm{Li}$

Federal Reserve Bank of Philadelphia

Department of Research

Ten Independence Mall

USA - PA 19106

wenli.li@phil.frb.org

\author{
Ishani Tewari \\ Yale School of Management \\ 135 Prospect Street \\ USA - New Haven, CT \\ ishani.tewari@yale.edu
}

\author{
Michelle J. White \\ Department of Economics \\ University of California, San Diego \\ USA - 92093-0508 La Jolla CA \\ miwhite@ucsd.edu
}

Current version: February 2014

The views expressed are those of the authors and do not necessarily represent those of the Federal Reserve Bank of Philadelphia, or the Federal Reserve System. 
Since the mortgage crisis began in 2008, an unprecedented 4.2 million home foreclosures have been completed in the U.S. - an average of 850,000 per year compared to 250,000 per year during the period 2000 to 2006 (CoreLogic, 2013). ${ }^{2}$ The number of foreclosures has also been very high in other countries such as Spain that experienced housing crises, even though homeowners there remain liable to repay their mortgages in full even after giving up their homes (Daley, 2010). Governments have tried various measures to reduce the number of foreclosures. In the U.S., Federal government programs under the Bush and Obama Administrations offered compensation to lenders if they modified underwater mortgages by reducing homeowners' monthly payments; but these programs were unsuccessful because few lenders were willing to allow modifications. ${ }^{34}$

In this paper, we study an alternative approach to reducing foreclosures - called mortgage strip-down or cramdown, which would allow bankruptcy judges to reduce the principle owed on underwater mortgages to the current market value of the home for homeowners who file for Chapter 13 bankruptcy. This approach has the advantage that underwater mortgages can be modified regardless of whether lenders consent, so that homeowners with underwater mortgages would have a bankruptcy alternative to defaulting and moving out of their homes. The Obama Administration proposed legislation in 2009 to allow strip-down of residential mortgages in Chapter 13, but Congress did not enact it due to heavy lobbying by mortgage lenders..$^{5}$ Our analysis is also relevant to another recent proposal for dealing with underwater

\footnotetext{
${ }^{2}$ Completed foreclosures are those in which title to the property passes to the mortgage lender and the homeowner either moves out or becomes a tenant.

3 The Bush and Obama Administration programs to reduce foreclosures were, respectively, "Hope for Homeowners" and the "Making Home Affordable Plan." The latter program required participating lenders to lower homeowners' monthly payments to $38 \%$ of their gross income; the government then paid the cost of lowering monthly payments to $31 \%$ of gross income. Neither program aided more than a few thousand homeowners. See Bajaj (2008), Bernard (2009), and Stolberg and Andrews (2009).

4 Various reasons have been proposed for why lenders refused to modify mortgages; these include the fact that doing so would force them to recognize their accounting losses, the fact that mortgage servicers were sometimes prevented from modifying mortgage terms by the terms of mortgage securitizations, the fact that servicers were incentivized to foreclose rather than to modify mortgages, and the fact that lenders expected some homeowners who defaulted to "self-cure". For discussion, see Adelino et al (2009) and Mayer et al (2009).

5 The proposed bills were the "Helping Families Save Their Homes Act of 2009" (H.R. 1106, 111 th $^{\text {Cong. }}$ (2009)), introduced in the House, and the "Helping Families Save Their Homes in Bankruptcy Act of 2009" (S. 61, 111 ${ }^{\text {th }}$ Cong. (2009)), introduced in the Senate.
} 
mortgages: that local governments use eminent domain to take underwater mortgages within their jurisdictions, compensate lenders for the mortgages based on the amount they would receive if they foreclosed, and give homeowners new mortgages with the principle reduced to current market value. ${ }^{6}$

Whether allowing strip-down of underwater home mortgages would improve economic efficiency is theoretically ambiguous. Allowing strip-down is beneficial since homeowners often default on their mortgages and move out when their mortgages are underwater, but lenders fail to maintain the vacant homes during the foreclosure process - the result is "zombie homes" that fall into disrepair, cause neighborhood blight, lower values of nearby homes, and deprive local governments of property tax revenue. The fact that borrowers and lenders do not bear the full cost of mortgage default and foreclosure means that too many foreclosures occur. ${ }^{7}$ However, allowing strip-down has the drawback that it erodes creditor protection by forcing lenders to give up some of their contractual remedies for default. This may reduce the supply of credit - the Mortgage Bankers Association argued that allowing strip-down would raise mortgage interest rates by at least $1 \frac{1 / 2}{2}$ percentage points. ${ }^{8}$

In this paper, we assess the link between the strength of protection provided to mortgage lenders and the terms of mortgage loans, using a quasi-experimental setting in which four of the eleven U.S. Courts of Appeal (circuit courts) decided between 1989 and 1992 to allow stripdown of residential mortgages in Chapter 13 bankruptcy and the U.S. Supreme Court decided in 1993 to abolish strip-down all over the U.S. The timing of these court decisions is plausibly exogenous to market conditions, since circuit courts can only decide legal questions when they receive an appeal of a case involving the question and, similarly, the Supreme Court only decides legal questions when it receives an appeal from a circuit court involving the question (although the Supreme Court - unlike the circuits - can either accept or reject appeals). We use a difference-in-difference approach that compares changes in mortgage approval rates, mortgage size, and interest rates in affected versus unaffected regions following each court decision.

\footnotetext{
${ }^{6}$ See Hockett (2013) and Dewan (2013) for discussion. 7 Campbell et al (2011) find that homes located 1/20 of a mile away from a foreclosure lose $1 \%$ of their value, using residential sale data from Massachusetts in the 1990's. The Center for Responsible Lending (2013) found that each foreclosure results in nearby homes losing a total of $\$ 23,000$ in value. See Craig (2014) for discussion of "zombie homes".

${ }^{8}$ For testimony against the bills in Congress by a representative of the Mortgage Bankers Association, see Kittle (2007). See www.mortgagebankers.org/NewsandMedia/PressCenter/59343.htm for a press release by the Mortgage Bankers Association on the bills.
} 
Our main results are that the Supreme Court decision to abolish strip-down had small but significant effects on mortgage credit availability, with lenders cutting interest rates by around 23 basis points, or $3 \%$, and increasing approval rates by 0.9 percentage points, or $1 \%$, in affected relative to unaffected regions. These changes occurred during the period three months after the decision relative to three months before, but only the approval rate change persisted over a longer time period. The small size of the reduction in interest rates when strip-down was abolished is noteworthy since it is less than one-sixth of the effect predicted by the Mortgage Bankers Association, which was at least 1/1/2 percentage points. We also find that the circuit court decisions to allow strip-down did not have consistent effects on the availability of mortgage credit-lenders did not change the terms of mortgage loans in two of the four circuits, they lowered interest rates in one of the remaining circuits and raised interest rates in the other. These inconsistent responses by lenders are probably due to the fact that the profitability of mortgage lending - as measured by serious delinquency rates on mortgages - does not appear to be significantly affected by whether strip-down is allowed or not. We conclude that if stripdown were adopted nationally, creditors' response is likely to be small and short-term.

Section 2 of the paper discusses bankruptcy and foreclosure law and the legal justification for allowing strip-down of mortgages in bankruptcy. Section 3 discusses the literature. In section 4, we consider whether lenders are predicted to respond to strip-down by changing the quantity or the price of mortgage loans, or both. Sections 5 and 6 discuss empirical specification and results. Section 7 concludes.

\section{Law of Bankruptcy and Foreclosure ${ }^{9}$}

There are two bankruptcy procedures, Chapters 7 and 13, both of which help homeowners who are at risk of default on their mortgages. Under Chapter 7, some or all of homeowners' unsecured debts are discharged, but the terms of mortgages and other secured loans remain unchanged. Homeowners must give up all of their assets above an exemption level set by their state of residence, but they are not obliged to use any of their future income to repay debt. Because mortgage loans are not changed or discharged in Chapter 7, the procedure does not directly help financially distressed homeowners save their homes. Nonetheless it helps

\footnotetext{
9 This discussion is based on U.S. bankruptcy law before the 2005 bankruptcy reform, since our empirical work uses pre-2005 data. See Eggum et al (2008) and White and Zhu (2010) for discussion of how Chapter 13 bankruptcy helps homeowners save their homes.
} 
homeowners indirectly, since discharge of unsecured debt reduces their obligation to pay nonmortgage debt and they may use the increase in ability to pay to avoid or cure their mortgage default.

Homeowners who wish to save their homes benefit more directly from filing under Chapter 13. Here they must propose a plan to repay some of their debt from future income, but they are not obliged to give up any of their assets. Repayment plans must last for 3 to 5 years. Homeowners who are in default on their mortgages can repay their mortgage arrears as part of their plans and, if they complete the full schedule of payments, then their original mortgage contracts are reinstated. The plan also covers unsecured debt and debtors may propose repaying as little as $1 \%$ of the amount owed. Only the bankruptcy judge must accept the repayment plan; lenders' consent is not required. Thus homeowners can save their homes in Chapter 13 and also receive the benefit of having some of their unsecured debts discharged. ${ }^{10}$ In the early 1990's, this was a valuable option to homeowners who had positive equity in their homes and therefore wished to avoid foreclosure.

During certain periods (discussed below), homeowners with underwater mortgages could also petition for mortgage strip-down in Chapter 13. Legally, strip-down "bifurcates" underwater mortgages into two parts: a secured part equal to the current market value of the home and an unsecured part equal to the difference between the mortgage principal and current market value. Because unsecured claims in Chapter 13 are only entitled to be paid their value in a Chapter 7 bankruptcy proceeding - which is usually very low-the division of the mortgage into two parts effectively discharges the underwater portion of the mortgage and reduces the mortgage principle to current market value of the home. ${ }^{11}$

U.S. bankruptcy law contains conflicting provisions concerning strip-down of residential mortgages in bankruptcy. One provision of the Bankruptcy Code, 11 U.S.C. §506, allows any type of secured debt to be bifurcated in bankruptcy and the underwater portion of the debt to be converted from secured to unsecured. However another provision of the Code, 11 U.S.C. $\S 1322(b)(2)$, forbids strip-down of mortgages if they are collateralized only by a single-family

\footnotetext{
${ }^{10}$ Some types of unsecured debts cannot be discharged in bankruptcy, including tax obligations, most student loans, and lawyers' fees for the bankruptcy itself. See White and Zhu (2010) for discussion. ${ }^{11}$ One factor that deters homeowners from using Chapter 13 bankruptcy is the high cost of filing. Average costs for debtors filing for bankruptcy during the period that we study were $\$ 1,600$ for Chapter 13 , compared to only $\$ 600$ for Chapter 7 (Flynn and Bermant, 2002). In Chapter 13, debtors often pay legal fees over time as part of the repayment plan.
} 
home that is the owner's principle residence. ${ }^{12}$ Because of the conflict between these two provisions, the issue of whether strip-down of residential mortgages is allowed in Chapter 13 has been litigated many times. A number of bankruptcy courts and U.S. district courts allowed stripdown of residential mortgages in Chapter 13 and, between 1989 and 1992, four U.S. circuit courts - the $9^{\text {th }}, 2^{\text {nd }}, 10^{\text {th }}$, and $3^{\text {rd }}$ - allowed it. Another circuit court - the $5^{\text {th }}$, decided a similar case in 1992, but did not allow strip-down. The remaining circuit courts never allowed stripdown, although some district courts within these circuits allowed it. Because strip-down of residential mortgages in Chapter 13 was allowed in some circuits but not others, the U.S. Supreme Court accepted an appeal on this issue and, in June 1993, it decided in the case of Nobelman v. American Savings Bank to abolish strip-down of residential mortgages all over the U.S. ${ }^{13}$ See figure 1 for a map showing the circuit court and district court regions and table 1 for a list of court decisions and dates. ${ }^{14}$

Our empirical work uses difference-in-difference to examine how the circuit court and Supreme Court decisions to allow and abolish strip-down of residential mortgages in Chapter 13 bankruptcy differentially affected the supply of mortgage loans in the regions where strip-down was temporarily allowed relative to the regions where it was never allowed.

\section{Literature Review}

Our analysis ties in closely with work examining the link between creditor protection and financial markets or - more broadly - between protection of contracts and the level of financial development. In a seminal work in law and finance, La Porta et al. (1997) show that countries with better investor and creditor protection have broader capital markets. Extending this work, Djankov et al. (2007) construct an index that measures the legal rights of creditors. This measure is used to assess the "power theories of credit" which argue that the supply of private credit depends crucially on the power of creditors to force repayment, grab collateral, or take over the firm. Laeven and Majnoni (2005) and Bae and Goyal (2009) find, in samples of bank loans from multiple countries, that banks respond to poor enforceability of contracts by increasing interest

\footnotetext{
12 See Elias (2011) and Levitin (2009) for discussion.

${ }^{13} 508$ U.S. 324, 968 F. 2 d 483, decided June 1, 1993.

14 Each Federal district court has a bankruptcy court that covers the same territory. Decisions of bankruptcy courts are appealed either to a bankruptcy appellate panel for the district or to the district court directly. Decisions of district courts can be appealed to the circuit court.
} 
rates, shortening maturities, and reducing loan amounts. In single country studies using data from Italy and India, Jappelli et al (2005) find higher credit availability in jurisdictions with greater judicial efficiency, i.e., faster court action when creditors sue to enforce their default rights, and Visaria (2009) finds similar effects when new debt recovery tribunals were introduced in India to speed up enforcement of creditors' rights. On the other hand, Lilienfeld-Toal et al (2010) present evidence that, if credit supply is inelastic rather than elastic, stronger creditor protection increases credit access for wealthy borrowers, but reduces it for small borrowers.

In the context of US consumer credit markets, several papers exploit cross-state variation in creditor protection to draw a causal link between the level of creditor protection and credit availability. Pence (2006) finds that mortgage sizes are 3 to $7 \%$ smaller in states with defaulterfriendly foreclosure laws. Lin and White (2001), Gropp et al. (1997) and Berkowitz and White (2004) examine the effect of variable bankruptcy exemptions across U.S. states on credit availability. These articles find that states with high exemption levels (which favor debtors by allowing them to keep more of their assets in bankruptcy) have higher rejection rates for home improvement loans, higher interest rates on car loans, and reduced lending to small businesses. Gropp et al. (1997) also find that high asset exemptions redistribute credit toward wealthier borrowers. Li et al. (2011) and Kuchler and Stroebel (2009) show that bankruptcy exemption levels also affect households' decisions to default on their mortgages.

Research focusing on the consequences of strip-down is sparse and mostly limited to qualitative discussion. Levitin (2009) was the first to consider the effects of allowing strip-down of mortgages in bankruptcy on the terms of new mortgage loans. His article provides a detailed legal and policy analysis, but only a rudimentary empirical analysis. ${ }^{15}$ Specifically, Levitin made use of the fact that, under current law, mortgages can be stripped down if they are secured by owner-occupied multi-family homes, residential properties that are held by investors, or vacation homes, but cannot be stripped down if they are secured by owner-occupied singlefamily homes. He obtained quotes for new mortgage loans for all four types of properties, holding property and borrower characteristics constant. He found that there were no appreciable differences between the terms of mortgages that were versus were not subject to strip-down, which he interpreted to imply introducing strip-down would not affect the terms of mortgage loans. A more recent paper by Goodman and Levitin (2012), written contemporaneously with

${ }_{15}$ J.K. Winn (1993-94) and Eggum et al (2008) also discuss strip-down of mortgages in Chapter 13. 
ours, also uses difference-in-difference to estimate the average effect of strip-down on mortgage interest rates. There are several key differences between their paper and ours. First, we examine the impact of strip-down on mortgage approval rates and loan size, in addition to the impact on interest rates. Second, we separately analyze the effects of the circuit court decisions to allow strip-down versus the Supreme Court decision to abolish strip-down. Doing so reveals considerable heterogeneity between the decisions to allow versus abolish strip-down as well as among the decisions to allow it. Finally, motivated by this finding, we dig deeper into the channels underlying these non-uniform findings and look into how allowing strip-down affects the profitability of lending across jurisdictions.

\section{Theoretical considerations}

How is the availability of mortgage strip-down in Chapter 13 predicted to affect both the supply of mortgage credit and the terms of mortgage loans? To answer this question, we must consider both the demand and supply sides of the mortgage market.

Turning first to the demand side, the availability of both bankruptcy and mortgage strip-down in bankruptcy affect demand for mortgages by providing partial insurance to debtors against the downside risk of borrowing. Bankruptcy provides debtors with partial wealth insurance, because unsecured debt can be discharged when debtors experience adverse events such as job loss or health problems that reduce their incomes. As a result, bankruptcy makes risk-averse individuals more willing to borrow and increases their demand for loans. ${ }^{16}$ Strip-down of mortgages in Chapter 13 bankruptcy also provides borrowers with partial wealth insurance, because part of their mortgage debt is discharged when the value of their homes falls enough to wipe out their home equity. The insurance provided by strip-down in Chapter 13 also raises risk-averse individuals' demand for mortgage loans.

The availability of strip-down also affects borrowers' probability of default. Regardless of whether strip-down is available or not, borrowers have an incentive to default on their mortgages when their home equity is negative, because by walking away from their homes, they wipe out their negative home equity. When there is no strip-down, borrowers' cost of default is the cost of purchasing a new home, obtaining a new mortgage, and moving. But when strip-down is available, the cost of default falls to the cost of filing for bankruptcy under Chapter 13.

${ }^{16}$ See White (2006) for discussion of the insurance view of bankruptcy. 
Therefore borrowers are predicted to default on their mortgages more often when strip-down is allowed.

Turning to the supply side, the availability of strip-down has two potential effects on lenders' profits: profits are predicted to fall because more homeowners default, but profits conditional on default may either rise or fall depending on whether lenders' loss when mortgages are strippeddown is higher or lower than their loss when they foreclose. Levitin (2009) argues that losses are lower under strip-down. But even if this were true, the availability of strip-down is likely to reduce lenders' profit because more homeowners default. ${ }^{17}$ Overall, the availability of stripdown is predicted both to increase demand for mortgages and reduce the supply of mortgages, so that lenders are predicted to increase interest rates. But the availability of strip-down could either increase or reduce the probability of mortgage applications being approved and the size of mortgage loans.

\section{Data, Specification and Results}

5.1 Data. We use two different data sources in order to get information on approval rates for mortgage applications, mortgage loan size, and interest rates.

The first is the Home Mortgage Disclosure Act (HMDA) data, which is a monthly census of nearly all home mortgage applications in the U.S. We restrict our sample to applications for conventional mortgages to purchase or refinance owner-occupied single-family homes, since the Supreme Court decision in the Nobelman case applied only to mortgages with these characteristics. ${ }^{18}$ For each loan application, we know whether the application was approved, the loan principle, the location of the property at the census tract level, the applicant's income, race and sex and whether there was a co-applicant (usually interpreted as marital status). All of these

\footnotetext{
${ }^{17}$ A third effect of strip-down on lenders' profits is that, because strip-down would occur only in regions where housing values have fallen, allowing it increases lenders' repayment risk by making mortgage defaults more positively correlated within regions.

${ }^{18}$ We drop mortgages to purchase or refinance second homes and investment properties, because they were never subject to the prohibition on strip-down. We also drop applications for home improvement loans, because they are not secured by the house, and for non-conventional mortgages, because repayment of these mortgages is guaranteed by the Federal Housing Administration or the Veterans Administration and lenders are unlikely to vary the terms of guaranteed mortgages in response to legal rules that affect default. We would also have liked to drop applications for mortgages on owner-occupied 2-to-4-family homes, but HMDA does not distinguish between single-family versus multi-family owneroccupied homes. However the number of mortgage applications for multi-family owner-occupied homes is small. We also drop observations in Hawaii and Alaska and we drop the top and bottom $0.5 \%$ of observations based on income and loan size. Finally, to keep sample sizes manageable, we take a 20\% random sample of the remaining data.
} 
variables are taken from the mortgage application. We also know whether the loan was for purchase or refinance, and type of lender. ${ }^{19}$ We add dummy variables for whether strip-down of mortgages in bankruptcy is allowed in the court district where the property is located, whether the Chapter 13 bankruptcy filing rate in the relevant district (lagged one month) is in the top 10\% of the national distribution, and whether the proportion of households in the census tract who are minorities exceeds $30 \%$. We also add average income in the metropolitan area where the property is located, the unemployment rate in the relevant county (lagged one month), and a house price index at the zipcode level (lagged one month). Except for the percent minority in the census tract, all of these variables are observed monthly. ${ }^{20}$ The Chapter 13 bankruptcy filing rate is entered because mortgage strip-down is only allowed when borrowers file under Chapter 13 and because network effects imply that individuals are more likely to hear about and file for bankruptcy under Chapter 13 if they live in a district with a higher Chapter 13 filing rate. ${ }^{21}$

The second dataset is the Monthly Interest Rate Survey (MIRS), a monthly sample of conventional mortgages that originated during the last week of each month. The fact that the MIRS data include only originated mortgages raises the possibility of selection bias, because rejected mortgage applications are excluded. We nonetheless examine the MIRS because it is the only source of data on interest rates during the period we study. MIRS includes information on interest rates, mortgage principle, lender type, and property location. No borrower characteristics or additional loan characteristics are available. We add the same regional-level variables as for the HMDA data.

Finally, we also examine data from the Mortgage Bankers Association on serious mortgage delinquency rates, defined as the proportion of mortgages in which payments are more than 90 days past due. For the period we study, data are available quarterly by state.

\subsection{Specification and results for the Supreme Court decision to abolish strip-down.}

We use a difference-in-difference model to estimate the effect on mortgage markets of the Supreme Court decision to abolish strip-down. The specification is:

19 Lender types include banks, credit unions, thrifts, and independent mortgage banks.

20 The average income by metropolitan area and the percent minority by census tract are constructed from HMDA data. The county-level unemployment rates are from Bureau of Labor Statistics. The house price index is from CoreLogic. Chapter 13 filing rates are from the Administrative Office of the U.S. Courts. ${ }^{21}$ See Fay et al (2003) for empirical evidence that bankruptcy filing rates are higher when the lagged aggregate bankruptcy rate in the district is higher. 


$$
\begin{gathered}
\text { Mortgage market outcome }=\alpha+\beta_{1} \text { Four circuits } * \text { Post }+\beta_{2} \text { Districts } * \text { Post } \\
+\gamma Z+\delta D+\lambda M+\mu T+\varepsilon .
\end{gathered}
$$

To simplify the notation, we drop subscripts indicating that the observations are for individual mortgages in a given month-year. Post denotes observations after the Supreme Court decision in June 1993, Four circuits denotes observations in the $9^{\text {th }}, 3^{\text {rd }}, 10^{\text {th }}$, and $2^{\text {nd }}$ circuit court regions where strip-down was allowed prior to the Supreme Court decision, and Districts denotes observations in district or bankruptcy courts where strip-down was allowed prior to the Supreme Court decision and which are not in any of the four circuits. Thus Four circuits*Post and Districts*Post are interaction terms that equal one for observations in circuits and districts where the Supreme Court decision abolished strip-down. $Z$ is the set of covariates mentioned above. $D$ denotes district-level fixed effects, $M$ denotes month fixed effects, and $T$ denotes district-level linear time trends. Because we include district-level fixed effects, we do not include Four circuits or Districts alone.

We use short sample periods of three months before to three months after the Supreme Court decision in order to examine whether lenders responded to the law change when it occurred and to reduce the possibility that we might be capturing the effect of divergent trends in affected relative to unaffected regions. ${ }^{22}$ In particular the latter might be a problem because the four circuits that allowed strip-down are mainly on the west coast and in the northeast, which often have divergent economic trends from the rest of the country. (We also use district-level linear time trends to allow for divergent linear trends across districts.)

The main coefficients of interest are $\beta_{1}$ and $\beta_{2}$, which measure the change in mortgage market outcomes after the Supreme Court decision in the circuits and districts that previously allowed strip-down relative to those where strip-down was never allowed. We distinguish between the effects of circuit court versus district court decisions, because circuit court decisions more definitively change the law.

For the HMDA data, the mortgage market outcomes we examine are whether mortgage applications were approved and the size of the mortgage loan that the borrower applied for. We use probit for the approval regressions and Tobit for the mortgage loan size regressions, with

\footnotetext{
22 Because the Supreme Court decision occurred on June 1, 1993, we assign June observations to the post
} period, so that our sample period covers March through August 1993. 
left-censoring for rejected applications. For the MIRS data, the dependent variables are the interest rate and the mortgage size and we use OLS for both. The predicted signs of $\beta_{1}$ and $\beta_{2}$ are ambiguous in the approval rate and loan size regressions and are negative in the interest rate regression. ${ }^{23}$

Figure 2, top panel, gives monthly average mortgage approval rates for the period of three months before to three months after the Supreme Court decision to abolish strip-down, using the HMDA data. These figures are constructed using the raw data. Treated observations are in the circuit court and district court regions where strip-down was allowed prior to the Supreme Court decision and control observations are in regions where strip-down was never allowed. We set approval rates and mortgage size for both groups equal to zero in May 1993, just before the Supreme Court decision, so that the figures for other months are relative to the levels in May 1993 for each group. Approval rates for the treated versus control groups have similar trends prior to the Supreme Court decision, but approval rates for the treated group increase relative to the control group after the decision and remain higher. These figures suggest that the Supreme Court decision resulted in a rise in approval rates and loan sizes in the treated relative to the control group. Figure 2, lower panel, gives the same data for mortgage loan size. Here the trends in the treated and control groups are quite different prior to the Supreme Court decision, but mortgage size increases by more after the decision in the treated group than in the control group. Figure 3 shows the same charts using MIRS data on interest rates and mortgage size. Interest rates for the treated group are below those for the control group both before and after the Supreme Court decision; while loan sizes rise by more after the decision for the control group than for the treated group. Neither of the figures using the MIRS data suggest that interest rates or loan sizes changed in the treated relative to the control group following the Supreme Court decision.

Table 2 gives summary statistics for both datasets for the period of three months before to three months after the Supreme Court decision.

Table 3 gives the benchmark regression results for the Supreme Court decision, using both data sets. $p$-values are shown in parentheses. In the approval rate regression, the coefficient of Four circuits*Post is 0.91 percentage points and statistically significant $(p=.02)$, suggesting that

\footnotetext{
${ }^{23}$ In all regressions, errors are clustered at the district level. We use weights to make the MIRS sample nationally representative. HMDA data are unweighted, since the sample covers nearly the entire population of mortgage applications.
} 
approval rates for mortgage applications rose after the Supreme Court decision in the affected relative to the unaffected circuits. The percent increase is $0.00913 / 0.813$, or $1.1 \%$. In the interest rate regression, the coefficient of Four circuits*Post is -23 basis points and statistically significant $(p<.01)$, or $3.4 \%$. Thus lenders both loosened credit rationing and reduced interest rates in the affected relative to the unaffected circuits following the Supreme Court decision, with the direction of the interest rate changesupporting our prediction. But we do not find any significant change in mortgage loan size in the affected relative to unaffected circuits after the decision. We also do not find significant changes in any of the mortgage market outcomes in the affected relative to unaffected districts.

Turning to other variables, one that is particularly of interest is the dummy for mortgages in districts where the lagged Chapter 13 filing rate is in the top decile, since more mortgages are likely to be stripped down in districts where Chapter 13 filings are more common. Surprisingly, we do not find in either dataset that lenders significantly changed approval rates or loans terms in these high Chapter 13 districts once we control for other variables. (Below, we also examine whether the difference-in-difference terms are larger in districts with high Chapter 13 filing rates. $)^{24}$

We did a number of specification checks and the results are shown in table 4. Each figure in table 4 gives the coefficient of Four circuits*Post from a separate regression. Only the results for the approval rate and interest rate regressions are shown, because the interaction term in the regressions explaining mortgage loan size were never significant. For the same reason, we also do not report the results for Districts*Post. The first line of table 4 repeats the results for Four circuits*Post from table 3. In the next line of table 4, we replace Post in equation (1) by Months since decision, where the number of months since the decision equals one, two or three. In this specification, the abolition of strip-down is assumed to have a gradually increasing effect on mortgage market outcomes, with the marginal effect remaining the same each month of the postperiod. The coefficient of the interaction term in this linear difference-in-difference specification is predicted to be approximately half the size of the coefficient of the interaction term in the benchmark. ${ }^{25}$ The interaction term in the regression explaining approval rates becomes

24 See Canner and Passmore (1994), Avery et al (1993) and www.ffiec.gov/hmda/history.htm for discussion of the large race and sex coefficients in HMDA.

25 This is because the average value of number of months after the Supreme Court decision is two, assuming that the number of observations is the same each month following the decision. 
insignificant in this specification, while the interaction term in the interest rate regression remains marginally significant ( $p=.06$ ), but drops from 23 to 9 basis points.

The next two lines examine whether lenders' response to the Supreme Court decision was stronger for high-risk borrowers. We classify borrowers as high-risk if they are located in districts with above-median Chapter 13 filing rates or if they obtained their mortgages from independent mortgage banks - which specialize in high-risk loans. In the next two sets of regressions, the sample is restricted to the relevant group of high-risk borrowers. For the HMDA samples, both interaction terms have larger coefficients in the high-risk subsamples than in the benchmark and the results are statistically significant: lenders increased approval rates by 1.6 percentage points after the Supreme Court decision in districts with high Chapter 13 filing rates and independent mortgage banks increased approval rates by 1.4 percentage points after the Supreme Court decision, compared to an increase of 0.9 percentage points in the benchmark. However the change in interest rates after the Supreme Court decision is smaller for the high-risk subsamples than for the full sample, suggesting that lenders did not expect the abolition of stripdown to affect high-risk borrowers more strongly than low-risk borrowers. In the fifth line of table 4, we rerun the benchmark model using a longer sample period of six months before to six months after the Supreme Court decision: the result for approval rates remains similar to the result in the benchmark, but the result for interest rates disappears. Finally in the last line of table 4, we repeat the analysis using a fake date of one year after the actual Supreme Court decision. The results were insignificant in both samples.

Overall, these results suggest that lenders responded to the Supreme Court decision to abolish mortgage strip-down by lowering interest rates in circuits that previously allowed stripdown relative to those that never allowed it: the decline was 24 basis points, or $3.4 \%$. This result is in line with our predictions, but the effect is small, short-term, and not particularly robust. We also found that lenders increased approval rates in affected relative to unaffected regions by 0.9 percentage points after the decision, or $1.1 \%$, and this result is more robust. We did not find any significant effect of the Supreme Court decision on the size of mortgage loans in affected relative to unaffected regions.

\subsection{Specification and results for the circuit court decisions to allow strip-down.}

Now turn to our analysis of the circuit court decisions to allow strip-down on mortgage market outcomes. The specification becomes: 


$$
\text { Mortgage market outcome }=\alpha+\beta_{3} \text { Circuit*Post }+\gamma Z+\delta D+\lambda M+\mu T+\varepsilon \text {. }
$$

Here we estimate separate regressions for each of the four circuit court decisions to allow stripdown, using sample periods of three months before to three months after each court's decision. Circuit is now a dummy that equals one for observations in the relevant circuit court region and Post is a dummy for months after each court's decision. For each regression, the treatment group is observations in the relevant circuit and the control group is observations in circuits and districts that never allowed strip-down. ${ }^{26}$ The major coefficient of interest is $\beta_{3}$, which is predicted to have the opposite sign from $\beta_{1}$ and $\beta_{2}$ in equation (1). The mortgage market outcome variables and the controls remain the same as in table 3.

We use MIRS data to estimate regressions for all four circuit court decisions. But because HMDA data are only available at the mortgage level starting January 1990, we cannot use these data to estimate regressions for the two earliest circuit court decisions, the $9^{\text {th }}$ and the $3^{\text {rd }}$. As a falsification test, we also estimate the same regressions for the $5^{\text {th }}$ circuit court, which decided not to allow strip-down in August 1992. For this regression, the coefficient of the interaction term is predicted to be insignificant. ${ }^{27}$

The results are given in table 5. Each figure in the table is the coefficient of Circuit- ${ }^{*}$ Post from a separate regression. Only two of the interaction terms are statistically significant-those in the regressions explaining interest rates for the $9^{\text {th }}$ and $3^{\text {rd }}$ circuit court decisions. They show that lenders raised interest rates by 9 basis points, or $0.9 \%$, in the $9^{\text {th }}$ circuit court region relative to other circuits after strip-down was allowed and the result is marginally significant $(p=.10)$. This response by lenders is in line with our predictions, since demand for mortgages is predicted to rise and supply is predicted to fall when strip-down is permitted. But, surprisingly, the next circuit court decision to allow strip-down — in the $3^{\text {rd }}$ circuit — resulted in a large fall of 34 basis points in interest rates relative to unaffected circuits, or 3.4\% $(p=.03)$. The last two circuit court

${ }^{26}$ Thus the $3^{\text {rd }}$ circuit court regression omits observations in the $9^{\text {th }}$ circuit, the $10^{\text {th }}$ circuit court regression omits observations in the $3^{\text {rd }}$ and $10^{\text {th }}$, and the $2^{\text {nd }}$ circuit regression omits observations in the $9^{\text {th }}, 3^{\text {rd }}$, and $10^{\text {th }}$ circuits. In all regressions, we also drop observations in districts that allowed strip-down, but are not in the $9^{\text {th }}, 3^{\text {rd }}, 10^{\text {th }}$ or $2^{\text {nd }}$ circuits.

${ }_{27}$ Summary statistics and full regression results are given in Appendix tables 1 and 2. Because all of the circuit court decisions occurred in the middle of the relevant month, we assign observations in the month of the decision to the post period. The time periods for the circuit court samples are July - December 1989 for the $9^{\text {th }}$ circuit, November 1989 - April 1990 for the $3^{\text {rd }}$ circuit, October 1990 - April 1991 for the $10^{\text {th }}$ circuit, January - June 1992 for $2^{\text {nd }}$ circuit, and May - October 1992 for the $5^{\text {th }}$ circuit. 
decisions to allow strip-down had no statistically significant effects on mortgage market outcomes. In addition, the results suggest that lenders did not change approval rates for mortgage applications or mortgage loan sizes following any of the circuit court decisions to allow strip-down. The placebo test using the $5^{\text {th }}$ circuit decision had, as expected, had no significant effects on any of the mortgage market outcomes. Overall, these results suggest that lenders did not respond strongly or consistently to the circuit court decisions to allow strip-down.

We also reran all of the regressions in table 5 using the linear difference-in-difference specification in which the dummy variable Post is replaced by the number of months since the decision. These results are shown in table 6. In this specification, the increase in interest rates following the $9^{\text {th }}$ circuit court decision remains positive and becomes more strongly significant ( $p$ $=.03$ ), suggesting that lenders' response to the strip-down decision gradually increased in size over the three months following the decision. The large negative interest rate response by lenders that we previously found in response to the $3^{\text {rd }}$ circuit court decision to allow strip-down disappears. But several of the results are surprising, including the large and significant increase in the size of mortgage loans in response to the $2^{\text {nd }}$ circuit court decision to allow strip-down$\$ 12,400$ ( $p=.04)$ - and the significant changes in the approval rate and interest rate in response to the $5^{\text {th }}$ circuit court decision, which is our placebo test. Thus some of the mortgage market responses to the circuit court decisions allowing strip-down are difficult to explain and do not support our predictions.

To investigate the increase in interest rates in the $3^{\text {rd }}$ circuit court region further, we reran the $3^{\text {rd }}$ circuit regressions using the sample period of the $9^{\text {th }}$ circuit court decision, or July to December 1989. Our hypothesis is that, at the time of the $9^{\text {th }}$ circuit decision, lenders may have anticipated that the $3^{\text {rd }}$ circuit would shortly follow the $9^{\text {th }}$ in allowing strip-down and might therefore have increased interest rates in the $3^{\text {rd }}$ circuit region in advance of the actual decision. ${ }^{28}$ But if lenders later decided that the availability of strip-down did not reduce the profitability of mortgage lending, then they might have reversed the increase in the $3^{\text {rd }}$ circuit region a few months later. The results of this regression, run using the linear difference-in-difference specification to allow lenders to respond gradually to the $3^{\text {rd }}$ circuit court decision, are shown in

28 The $3^{\text {rd }}$ circuit court case involving strip-down was decided in February 1990, which was four months after the $9^{\text {th }}$ circuit court decision. Although we could not obtain the dates when the $3^{\text {rd }}$ circuit strip-down case was appealed or argued, these events were likely to have occurred around the time of the $9^{\text {th }}$ circuit decision or shortly thereafter. 
the last row of table 6. The coefficient of the interaction term in fact has a significant and positive coefficient of $.178(p=.02)$, which supports the hypothesis that lenders in the $3^{\text {rd }}$ circuit region initially raised interest rates following the $9^{\text {th }}$ circuit court decision, when they anticipated that the $3^{\text {rd }}$ circuit would follow the $9^{\text {th }}$ in allowing strip-down, but reversed the increase a few months later. The reversal in the $3^{\text {rd }}$ circuit and the lack of a response by lenders to the $10^{\text {th }}$ and $2^{\text {nd }}$ circuit courts' decisions allowing strip-down suggest that lenders gradually learned that stripdown had little effect on the profitability of mortgage lending. We also reran the $9^{\text {th }}$ circuit regressions using the $3^{\text {rd }}$ circuit sample period to see if lenders in the $9^{\text {th }}$ circuit also reversed their initial increase in interest rates. While the sign of the interaction term shifts from positive to negative in the later sample period, it is not significant.

In the next section, we examine whether the lack of a strong response by lenders to the four circuit court decisions to allow strip-down can be explained by the fact that strip-down has little effect on the profitability of mortgage lending.

\subsection{The relationship between strip-down and mortgage default rates.}

As discussed above, the profitability of lending depends on both the probability that borrowers default and the cost to lenders of default when it occurs. We cannot measure the latter, but we can obtain data on the probability of serious mortgage delinquency, defined as the fraction of mortgages that are more than 90 days delinquent. We use serious mortgage delinquency as our measure of default, since homeowners who are in default for more than 90 days on their mortgages are unlikely to self-cure. The profitability of mortgage lending is unambiguously and negatively related to serious delinquency rates, because higher delinquency rates reduce lenders' profit even if strip-down saves them money by reducing the number of foreclosures conditional on default. We hypothesize that we do not find a strong relationship between whether mortgage strip-down is allowed in bankruptcy and the terms of new mortgage loans because the availability of strip-down has little or no effect on serious delinquency rates.

To examine this relationship, we obtained data on serious mortgage delinquency rates during the early 1990's. The best available data are aggregate delinquency rates at the state-quarter level. We constructed separate samples of delinquency rates for periods of six months before to six months after each circuit court decision allowing strip-down and the Supreme Court decision abolishing strip-down. Then we ran separate regressions for each court decision, using the same 
interaction terms as in equations (1) and (2), plus state fixed effects. We expect the coefficients of the interaction terms in the circuit court regressions to be positive, since allowing strip-down reduces homeowners' cost of default, and we expect the coefficient in the Supreme Court regression to be negative. But an alternative is that homeowners' default rates do not change in response to the availability of strip-down in bankruptcy, in which case all of the interaction terms would be insignificant.

The results are shown in table 7, left-hand column. The first two circuit court decisions to allow strip-down, in the $9^{\text {th }}$ and $3^{\text {rd }}$ circuits, are not associated with significant changes in serious delinquency rates. The final two circuit court decisions allowing strip-down, in the $10^{\text {th }}$ and $2^{\text {nd }}$ circuits, are significantly related to serious delinquency rates, but the coefficient is positive as predicted in the $2^{\text {nd }}$ circuit while it is negative in the $10^{\text {th }}$ circuit. The result for the Supreme Court decision is insignificant. We also ran the model for the $5^{\text {th }}$ circuit court decision-again as a placebo test - and the result is insignificant, as expected. These results suggest that lenders' profit from mortgage lending was not strongly affected by whether strip-down was allowed or not in the relevant region, because default rates by homeowners mainly remained unchanged. The right-hand column of table 7 shows the results of rerunning the same regressions, but assuming that serious delinquency rates respond to changes in the availability of strip-down with a one-quarter lag. The results are similar to those with no lag, except that the positive result for the $2^{\text {nd }}$ circuit court decision disappears. These results suggest that, except in the $10^{\text {th }}$ circuit, serious delinquency rates did not respond to changes in the availability of strip-down.

Overall, these results suggest that lenders did not respond strongly to the circuit courts' decisions to allow strip-down of mortgages in Chapter 13, probably because strip-down had little effect on the profitability of mortgage lending. Our results suggest that lenders responded asymmetrically to court decisions to allow versus abolish strip-down - they did not consistently respond to the circuit court decisions to allow strip-down, but they lowered interest rates in response to the Supreme Court decision to abolish strip-down. We cannot tell whether this asymmetry reflects the greater salience of Supreme Court decisions or the fact that circuit court decisions are frequently reversed on appeal, while Supreme Court decisions cannot be appealed.

6. Conclusion. We examined the effect on mortgage loans of four circuit court decisions to allow strip-down of residential mortgages in Chapter 13 bankruptcy and the later Supreme 
Court decision to abolish it. Using difference-in-difference, our main result is that the circuit court decisions allowing strip-down did not affect the terms of mortgage loans, but the Supreme Court decision abolishing strip-down caused lenders to lower interest rates to fall by 13 - 16 basis points and to loosen credit rationing by around $1 \%$. We think that the overall effects of strip-down on mortgage markets are small because strip-down had little effect on lenders' profit from mortgage lending, as evidenced by the fact that (except in the $10^{\text {th }}$ circuit region) serious mortgage delinquency rates did not change in response to the court decisions.

The fact that the results are small suggests that allowing strip-down in Chapter 13 bankruptcy would not seriously disrupt the mortgage market or strongly reduce the supply of mortgage loans. Thus mortgage strip-down could be a worthwhile new approach to reducing foreclosures.

One final issue is what our results imply concerning the recent proposal that local governments take underwater mortgages by eminent domain and issue new, smaller mortgages to homeowners. Some lenders have announced that if local officials proceed with the eminent domain proposal, they will cease making mortgage loans in the affected jurisdictions. We think that the key difference between mortgage strip-down and the eminent domain proposal is that eminent domain will simultaneously strip-down all of the underwater mortgages within a jurisdiction, regardless of whether homeowners would have filed for Chapter 13 bankruptcy and sought strip-down on their own. Such concerted action that reduces the value of all underwater mortgages within a jurisdiction would harm lenders by much more than allowing strip-down in Chapter 13. 
Figure 1:

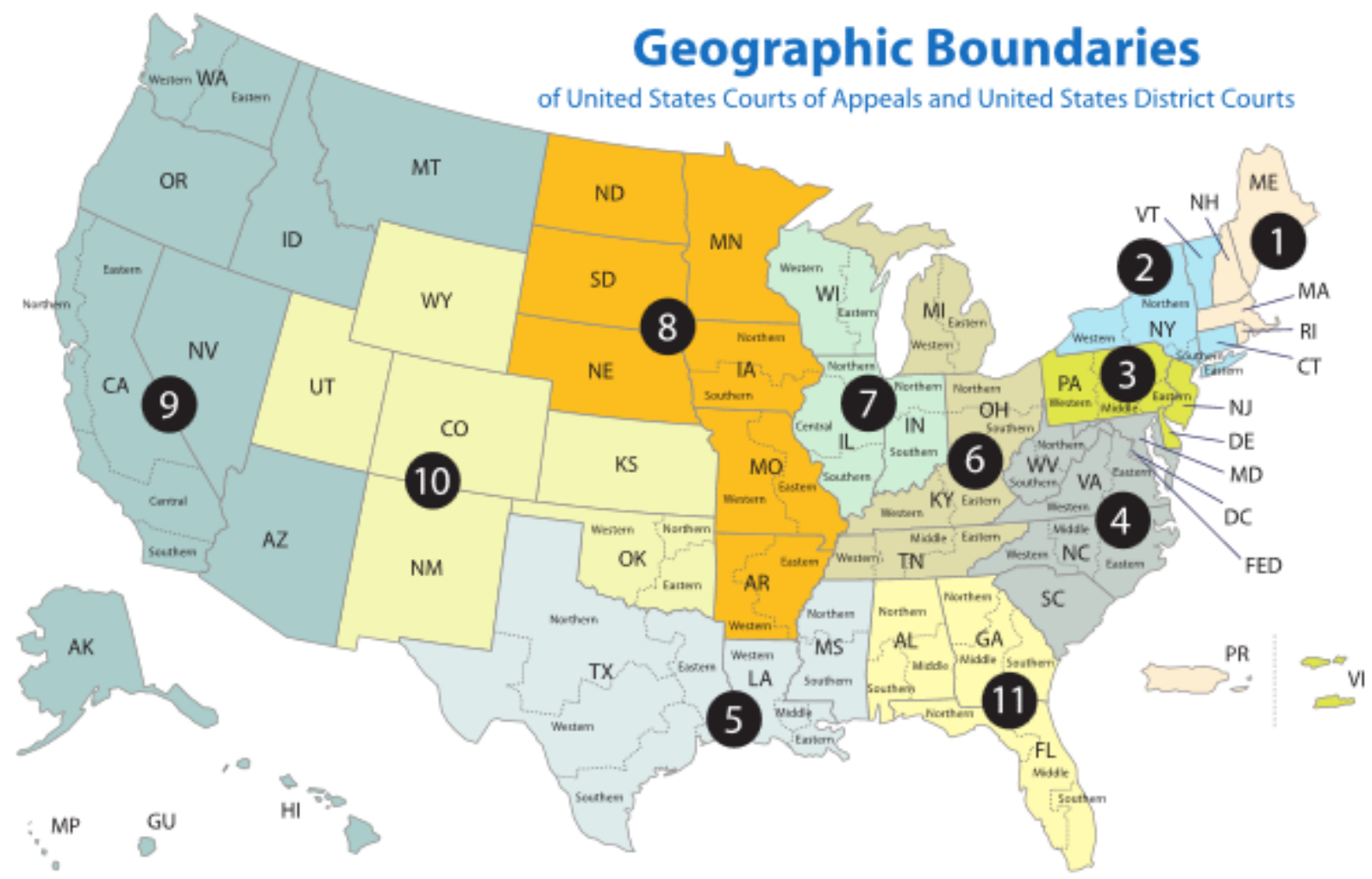


Figure 2:

\section{Approval Rates and Loan Size by Treated versus Control Groups: HMDA Data}

\section{Approval rates:}

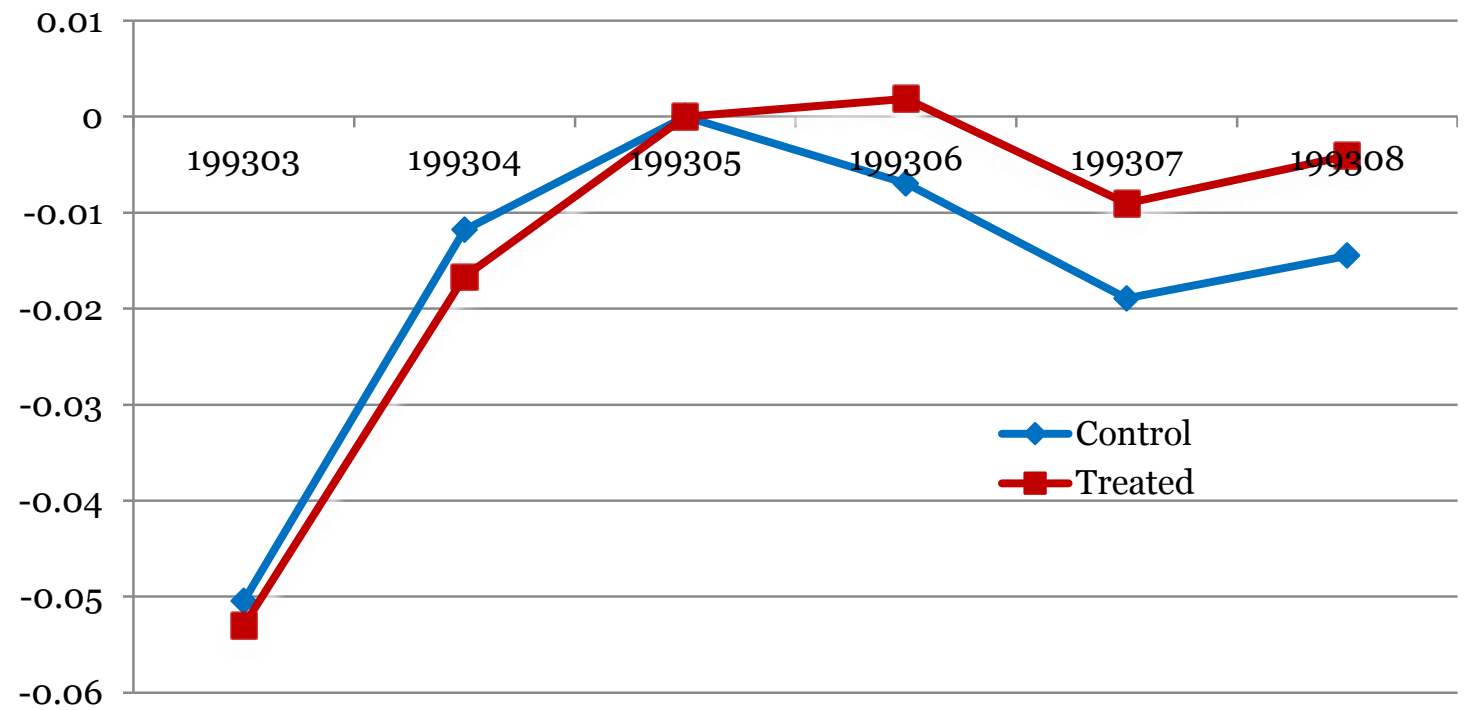

\section{Loan Size:}

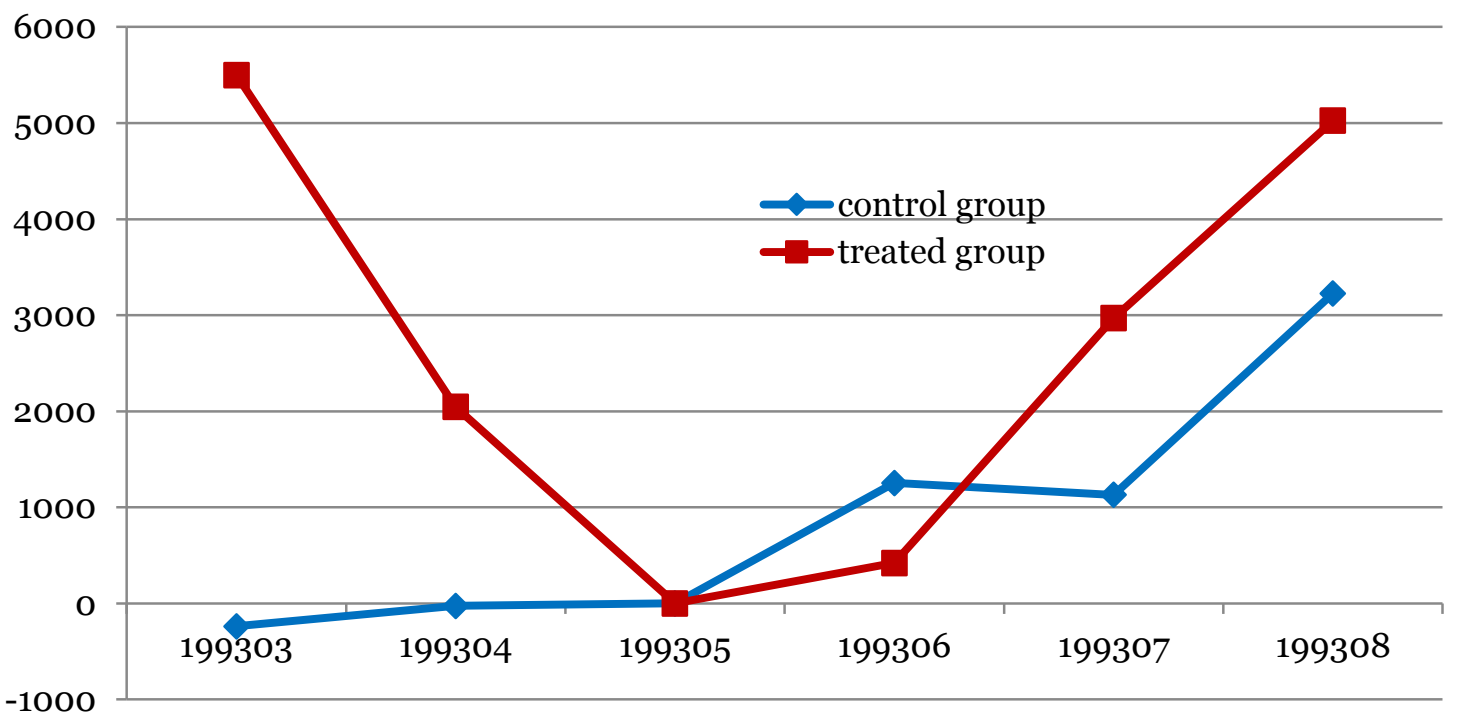

Notes: The data are average monthly approval rates for mortgages for the period three months before to three months after the Supreme Court decision. For both the treated and control groups, the figures for May 1993 are set equal to zero and figures for other months are differences relative to May 1993. 
Figure 3:

\section{Interest Rates and Loan Size by Treated versus Control Groups MIRS Data}

\section{Interest rates:}

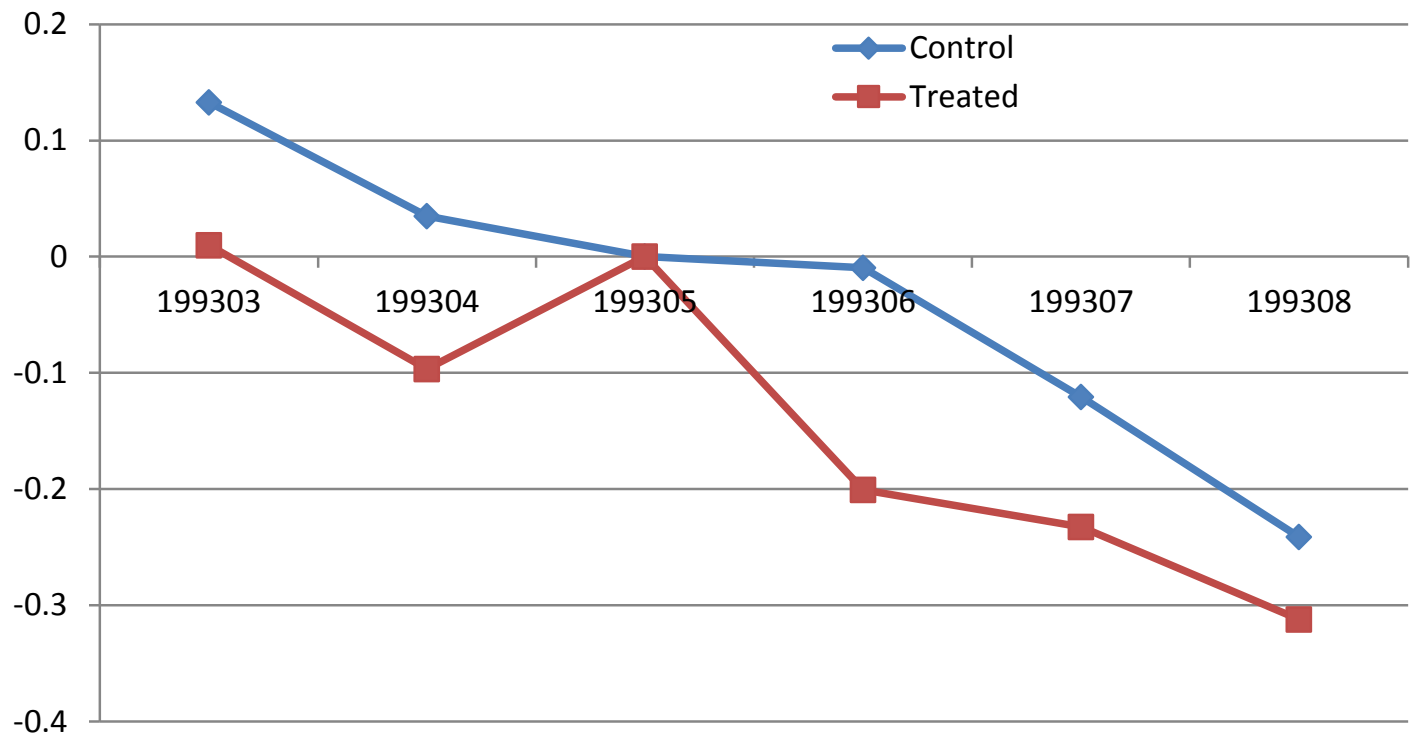

Size:

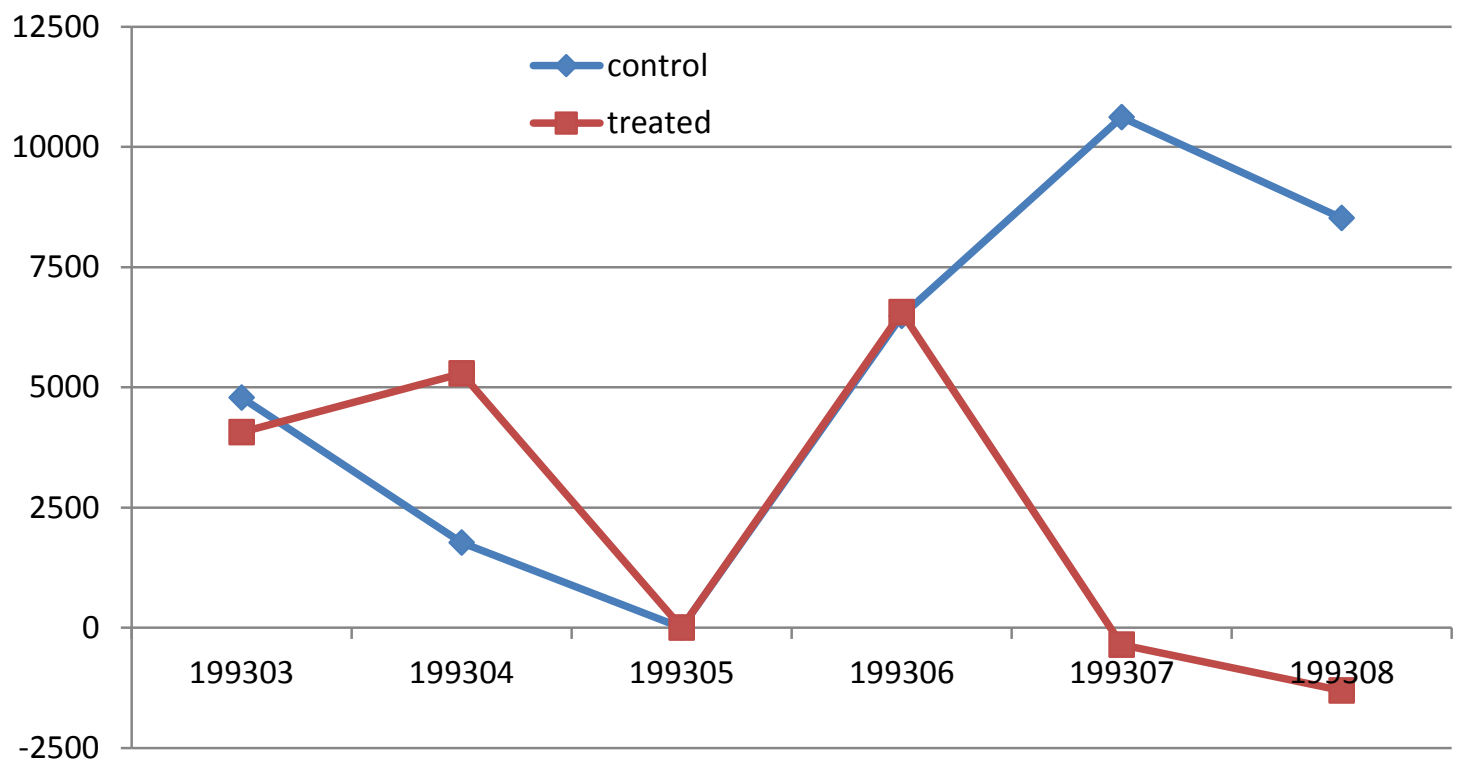

Notes: The data are average monthly interest rates and loan sizes for mortgages originated during the period six months before to six months after the Supreme Court decision. For both the treated and control groups, the figures for May 1993 are set equal to zero and the figures for other months are differences relative to May 1993. 
Table 1:

U.S. Court Decisions Allowing and Disallowing Strip-Down of Residential Mortgages

District and Bankruptcy Court Decisions Allowing Strip-down

\begin{tabular}{|c|c|c|}
\hline District & Circuit & Date \\
\hline Massachusetts & 1 & April 1991 \\
\hline Rhode Island & 1 & Feb 1990 \\
\hline Maine & 1 & Jan 1993 \\
\hline Connecticut & 2 & July 1991 \\
\hline Pennsylvania, E district & 3 & May 1988 \\
\hline New Jersey & 3 & Jan 1989 \\
\hline Virginia, $\mathrm{W}$ district & 4 & July 1994 \\
\hline Virginia, E district & 4 & Feb 1990 \\
\hline North Carolina, E district & 4 & May 1991 \\
\hline West Virginia, S district & 4 & May 1991 \\
\hline Indiana, $\mathrm{N}$ district & 5 & Dec 1989 \\
\hline Ohio, $\mathrm{S}$ district & 6 & Feb 1989 \\
\hline Michigan, W district & 6 & June 1992 \\
\hline Michigan, E district & 6 & Feb 1993 \\
\hline Tennessee, $\mathrm{W}$ district & 6 & Jan 1992 \\
\hline Illinois, $\mathrm{N}$ district & 7 & April 1990 \\
\hline Oregon & 9 & Dec 1988 \\
\hline New Mexico & 10 & Oct 1990 \\
\hline Kansas & 10 & Sept 1987 \\
\hline Oklahoma, W district & 10 & Nov 1989 \\
\hline Georgia, Middle district & 11 & Nov 1992 \\
\hline Alabama, $\mathrm{N}$ district & 11 & April 1992 \\
\hline
\end{tabular}

Circuit Court Decisions:

\begin{tabular}{|c|c|c|}
\hline Circuit & Type of decision & Date \\
\hline 9 & Allowed strip-down & October 1989 \\
\hline 3 & Allowed strip-down & February 1990 \\
\hline 10 & Allowed strip-down & January 1991 \\
\hline 2 & Allowed strip-down & April 1992 \\
\hline 5 & Did not allow strip-down & August 1992 \\
\hline
\end{tabular}

Notes: The Supreme Court decision abolishing strip-down occurred on June 1, 1993. 
Table 2:

Summary Statistics: Supreme Court Samples

\begin{tabular}{|l|c|c|}
\hline & HMDA & MIRS \\
\hline If loan approved (percent) & $81.3(39.0)$ & -- \\
\hline Loan size, if approved (000\$) & $106(75.8)$ & $111(66.3)$ \\
\hline Interest rate (percent) & -- & $0.11(1.05)$ \\
\hline Circuits 2,3,9 and 10 & 0.445 & 0.464 \\
\hline Districts & 0.211 & -- \\
\hline Income (000\$) & $65.7(48.4)$ & -- \\
\hline If African-American applicant & $0.0326(0.178)$ & -- \\
\hline If other non-white applicant & $0.0881(.283)$ & -- \\
\hline If female applicant & $0.160(0.367)$ & $6.52(2.36)$ \\
\hline If married applicant & $0.659(.474)$ & $42.9(7.26)$ \\
\hline If refinance (versus purchase) & $7.22(2.09)$ & $0.429(.752)$ \\
\hline $\begin{array}{l}\text { Lagged unemployment rate } \\
(\%, \text { MSA) }\end{array}$ & $43.7(7.90)$ & $0.00010(.00008)$ \\
\hline Income (000\$) (MSA) & $0.373(0.678)$ & \\
\hline $\begin{array}{l}\text { Lagged house price growth rate } \\
(\%) \text { (MSA) }\end{array}$ & $0.00011(0.00009)$ & \\
\hline $\begin{array}{l}\text { Chapter 13 filing rate (district) } \\
\text { If minority percent > 30 } \\
\text { (census tract) }\end{array}$ & $0.174(0.380)$ & \\
\hline
\end{tabular}

Notes: The samples cover March through August 1993, which is 3 months before to 3 months after the Supreme Court strip-down decision on June 1, 1993. Dollar figures are in current (1993) dollars. Standard errors are in parentheses. 
Table 3:

Effects of the Supreme Court Decision to Abolish Strip-down:

Benchmark Results

\begin{tabular}{|c|c|c|c|c|}
\hline & $\begin{array}{c}\text { Approval rate } \\
\text { (Percentage } \\
\text { points) } \\
\text { (HMDA) }\end{array}$ & $\begin{array}{c}\text { Mortgage loan } \\
\text { size } \\
(\$) \\
\text { (HMDA) }\end{array}$ & $\begin{array}{c}\text { Interest rate } \\
\text { (Percentage } \\
\text { points) } \\
\text { (MIRS) }\end{array}$ & $\begin{array}{c}\text { Mortgage loan } \\
\text { size } \\
(\$) \\
\text { (MIRS) }\end{array}$ \\
\hline $\begin{array}{l}\text { Four circuits } \\
* \text { Post }\end{array}$ & $0.913 * *(.02)$ & $24.3(.96)$ & $-0.229 * * *(.01)$ & $680(.90)$ \\
\hline Districts*Post & $-0.0252(.96)$ & $1,020(.12)$ & $0.0417(.63)$ & $-9,740(.12)$ \\
\hline $\begin{array}{l}\text { If Chapter } 13 \\
\text { filing rate is } \\
\text { highest decile }\end{array}$ & $-0.506(.30)$ & $-168(.83)$ & $-0.0296(.48)$ & $1,630(.32)$ \\
\hline $\begin{array}{l}\text { If African- } \\
\text { American }\end{array}$ & $-11.2 * * *(.00)$ & $-17,900 * * *(.00)$ & -- & -- \\
\hline If other non-white & $-4.28 * * *(.00)$ & $5,930 * * *(.00)$ & -- & -- \\
\hline If female & $0.140(.60)$ & $-6,470 * * *(.00)$ & -- & -- \\
\hline If married & $4.14 * * *(.00)$ & $10,800 * * *(.00)$ & -- & -- \\
\hline Income & $0.0392 * * *(.00)$ & $700 * * *(.00)$ & -- & -- \\
\hline $\begin{array}{l}\text { If refinance } \\
\text { (versus purchase) }\end{array}$ & $5.09 * * *(.00)$ & $-7,530^{* * * *}(.00)$ & -- & -- \\
\hline $\begin{array}{l}\text { If minority } \\
\text { percent }>30\end{array}$ & $-4.49 * * *(.00)$ & $-19,300^{* * *}(.00)$ & $0.0143(.79)$ & $7,920 * *(.01)$ \\
\hline $\begin{array}{l}\text { Unemployment } \\
\text { rate (lagged) }\end{array}$ & $-0.00363(.92)$ & $90.2(.47)$ & $0.0129(.11)$ & $-1,830 * *(.02)$ \\
\hline MSA income (\$) & $0.289 * * *(.00)$ & $2,460 * * *(.00)$ & $\begin{array}{c}-9.48 \mathrm{e}-06^{* *} \\
(.02)\end{array}$ & $2,120 * * *(.000)$ \\
\hline $\begin{array}{l}\text { Monthly house } \\
\text { price growth rate }\end{array}$ & $-0.00337(.30)$ & $-1,010 *(.08)$ & $-1.18(.50)$ & $30,400(.63)$ \\
\hline Constant & -- & $-67,900^{* * *}(.00)$ & $8.66 * *(.00)$ & $11,500(.49)$ \\
\hline District dummies & $\mathrm{Y}$ & $\mathrm{Y}$ & $\mathrm{Y}$ & $\mathrm{Y}$ \\
\hline $\begin{array}{l}\text { District-level time } \\
\text { trends }\end{array}$ & $\mathrm{Y}$ & $\mathrm{Y}$ & $\mathrm{Y}$ & $\mathrm{Y}$ \\
\hline Month dummies & $\mathrm{Y}$ & $\mathrm{Y}$ & $\mathrm{Y}$ & $\mathrm{Y}$ \\
\hline Sample size & 774,000 & 774,000 & 63,700 & 63,700 \\
\hline R-squared & .051 & .030 & .12 & .26 \\
\hline
\end{tabular}

Notes: $p$-values are in parentheses. Probit results are given as marginal effects. The sample period is April through September 1993, or three months before to three months after the decision date of June 1, 1993. The HMDA regressions contain a dummy for missing race - these are not reported. MIRS regressions are weighted by sample weights. $* * *$ and $* * *$ indicate statistical significance at the $10 \%, 5 \%$ and $1 \%$ levels, respectively. Standard errors are clustered at the district level. 
Table 4:

Effects of the Supreme Court Decision to Abolish Strip-down: Specification Checks, Subsamples, and Fake Date Analysis

\begin{tabular}{|l|c|c|}
\hline & $\begin{array}{c}\text { Approval rate } \\
\text { (HMDA) }\end{array}$ & $\begin{array}{c}\text { Interest rate } \\
\text { (MIRS) }\end{array}$ \\
\hline Benchmark results & $0.913^{* *}(.017)$ & $-0.236^{* * *}(.01)$ \\
\hline $\begin{array}{l}\text { Linear diff-in-diff specification } \\
\text { (Months since S. Court decision*post) }\end{array}$ & $0.239(.41)$ & $-0.0921^{*}(.06)$ \\
\hline Chapter 13 filing rate > median & $1.56^{* *}(.04)$ & $-0.182^{* * *}(.01)$ \\
\hline Lender is independent mortgage bank & $1.42^{* *}(.05)$ & $-0.0841^{*}(.08)$ \\
\hline Six month before/after sample period & $1.04^{* * *}(.01)$ & $-0.0912(.24)$ \\
\hline Fake date (one year later) & $-0.831(.13)$ & $-0.114(.12)$ \\
\hline
\end{tabular}

Notes: Each figure is the coefficient of Four circuits*Post in a separate regression. Only results explaining approval rates and the interest rate are reported, since the interaction terms in the loan size regressions are never significant. The linear difference-in-difference specification assumes that the Post effect changes at the same rate each month after the Supreme Court decision in the affected relative to unaffected circuits. The high Chapter 13 subsample consists of mortgages on properties located in districts with above-median Chapter 13 filing rates. The independent mortgage bank subsample consists of mortgages originated by independent mortgage banks, which specialize in riskier loans. The six month before/after sample period runs from January - December 1993. The fake date analysis shifts the sample period one year later. The specification for all of the regressions is otherwise the same as in table 3 and the notes to table 3 apply. $p$-values are in parentheses. *** and *** indicate statistical significance at the $10 \%, 5 \%$ and $1 \%$ levels, respectively. Standard errors are clustered at the district level. 


\section{Table 5:}

\section{Effects of Circuit Court Decisions to Allow Strip-down: Benchmark Results}

\begin{tabular}{|l|c|c|c|c|}
\hline & $\begin{array}{c}\text { Approval rate } \\
\text { (Percentage } \\
\text { points) } \\
\text { (HMDA) }\end{array}$ & $\begin{array}{c}\text { Mortgage } \\
\text { principle } \\
\text { (\$) } \\
\text { (HMDA) }\end{array}$ & $\begin{array}{c}\text { Interest rate } \\
\text { (Percentage } \\
\text { points) } \\
\text { (MIRS) }\end{array}$ & $\begin{array}{c}\text { Mortgage } \\
\text { principle } \\
\text { (\$) } \\
\text { (MIRS) }\end{array}$ \\
\hline Circuit 9 & -- & -- & $0.0898^{*}(.10)$ & $1,490(.74)$ \\
\hline Circuit 3 & -- & -- & $-0.343 * *(.03)$ & $8,530(.42)$ \\
\hline Circuit 10 & $-1.32(.45)$ & $-2,020(.57)$ & $0.0280(.89)$ & $9,500(.46)$ \\
\hline Circuit 2 & $0.260(.87)$ & $493(.75)$ & $0.0833(.49)$ & $193(.96)$ \\
\hline $\begin{array}{l}\text { Circuit 5 (did not } \\
\text { allow strip-down) }\end{array}$ & $-0.767(.32)$ & $1,030(.74)$ & $-0.0425(0.71)$ & $5,530(0.32)$ \\
\hline
\end{tabular}

Notes: Each figure is the coefficient of Circuit $^{*}$ Post in a separate regression. $P$-values are in parentheses. Sample periods for each regression are three months before to three months after each court decision. *, ** and *** indicate statistical significance at the $10 \%, 5 \%$ and $1 \%$ levels, respectively. Standard errors are clustered at the district level. All regressions contain available covariates, district fixed effects, month fixed effects and district linear time trends. 
Table 6:

Effects of Circuit Court Decisions to Allow Strip-down:

Linear Difference-in-Difference Model

\begin{tabular}{|l|c|c|c|c|}
\hline & $\begin{array}{c}\text { Approval rate } \\
\text { (Percent) } \\
\text { (HMDA) }\end{array}$ & $\begin{array}{c}\text { Mortgage } \\
\text { principle } \\
(000 \$) \\
\text { (HMDA) }\end{array}$ & $\begin{array}{c}\text { Interest rate } \\
\text { (Percent) } \\
\text { (MIRS) }\end{array}$ & $\begin{array}{c}\text { Mortgage } \\
\text { principle } \\
(000 \$) \\
\text { (MIRS) }\end{array}$ \\
\hline Circuit 9 & -- & -- & $0.0924 * *(.03)$ & $-2,050(.46)$ \\
\hline Circuit 3 & -- & -- & $0.0681(.53)$ & $3,580(.61)$ \\
\hline Circuit 10 & $0.680(.36)$ & $1,830(.46)$ & $-0.0471(.64)$ & $-12,200(.35)$ \\
\hline Circuit 2 & $1.03(.46)$ & $1,550(.42)$ & $-0.131(.26)$ & $12,400^{* *}(.04)$ \\
\hline $\begin{array}{l}\text { Circuit 5 (did not } \\
\text { allow strip-down) }\end{array}$ & $-2.18 * * *(.00)$ & $-788(.64)$ & $0.282^{*}(.10)$ & $2,180(.70)$ \\
\hline $\begin{array}{l}\text { Circuit 3, using the } \\
\text { circuit 9 sample } \\
\text { period }\end{array}$ & -- & -- & $0.178^{* *}(.02)$ & $-366(.93)$ \\
\hline
\end{tabular}

Notes: Figures shown are the coefficients of the interaction term, (Months since decision*Post). Other notes to table 5 apply to table 6 . 
Table 7:

Effects of Court Decisions to Allow Strip-down on Serious Delinquency Rates

\section{MIRS}

\begin{tabular}{|l|c|c|}
\hline & $\begin{array}{c}\text { Serious } \\
\text { Delinquency Rate, } \\
\text { Current Quarter }\end{array}$ & $\begin{array}{c}\text { Serious } \\
\text { Delinquency Rate, } \\
\text { Lagged One } \\
\text { Quarter }\end{array}$ \\
\hline Circuit 9 & $-0.341(.20)$ & $0.0948(.38)$ \\
\hline Circuit 3 & $0.166(.17)$ & $0.163(.56)$ \\
\hline Circuit 10 & $-0.232 * * *(.002)$ & $-0.249 * * *(.00)$ \\
\hline Circuit 2 & $0.102 *(.055)$ & $-0.0120(.88)$ \\
\hline $\begin{array}{l}\text { Circuit 5 (did not allow strip- } \\
\text { down) }\end{array}$ & $-0.0703(.183)$ & $0.0574(.59)$ \\
\hline $\begin{array}{l}\text { Supreme Court (abolished strip- } \\
\text { down) }\end{array}$ & $0.0143(.77)$ & $-0.00653(.90)$ \\
\hline
\end{tabular}

Notes: Each entry is the coefficient of Circuit*Post or Four circuits*Post in a separate regression. For each regression, the sample period is six months before to six months after the relevant court decision. *,** and *** indicate statistical significance at the 10\%,5\% and 1\% levels, respectively Standard errors are clustered at the state level. All regressions include state and quarter fixed effects and state linear trends. 


\section{References}

Adelino, Manuel, Kristopher Gerardi, and Paul S. Willen, "Why Don't Lenders Renegotiate More Home Mortgages? Redefaults, Self-Cures, and Securitization." Federal Reserve Bank of Boston Public Policy Discussion Paper 09-4 (2009).

Avery, Robert B., Patricia E. Beeson, and Mark S. Sniderman, “Accounting for Racial Differences in Housing Credit Markets,” FRB Cleveland, Working Paper 9310, 1993.

Bae, Kee-Hong, and Vidhan K. Goyal. "Creditor rights, enforcement, and bank loans." The Journal of Finance 64, no. 2 (2009): 823-860.

Bajaj, V., "U.S. Vows More Help for Homeowners,” New York Times, October 23, 2008.

Berkowitz, Jeremy, and Richard Hynes, "Bankruptcy Exemptions and the Market for Mortgage Loans," Journal of Law \& Economics, vol. 42(2), pp. 809-830, 1999.

Bernard, Tara S., "Slow Start to U.S. Plan for Modifying Mortgages," New York Times, May 13, 2009.

Canner, Glenn B., and Wayne Passmore, "Residential Lending to Low-Income and Minority Families: Evidence from the 1992 HMDA Data." Federal Reserve Bulletin, vol. 80:2, Feb. 1994, pp. 79-108.

Craig, Susanne, "A New Effort in Albany to Put Lenders in Charge of Abandoned Properties," New York Times, February 9, 2014.

Dewan, Shaila, "More Cities Consider Using Eminent Domain to Halt Foreclosures," New York Times, November 15, 2013. www.nytimes.com/2013/11/16/business/more-cities-considereminent-domain-to-halt-foreclosures.html.

Djankov, Simeon, Caralee McLiesh, and Andrei Shleifer. "Private credit in 129 countries." Journal of Financial Economics 84, no. 2 (2007): 299-329.

Eggum, John, Katherine Porter and Tara Twomey, "Saving Homes in Bankruptcy: Housing Affordability and Loan Modification," Utah Law Review, vol. 2008:3 (2008): 1123-1168.

Elias, Stephen, The New Bankruptcy: Will It Work for You? $4^{\text {th }}$ Edition. Berkeley, CA: Nolo Press, 2011.

Fay, Scott, Erik Hurst and Michelle J. White, "The Household Bankruptcy Decision," American Economic Review, vol. 92:3, June 2002, pp. 708-718.

Flynn, Ed, and Gordon Bermant, "Bankruptcy by the Numbers: A Tale of Two Chapters: Financial Data." American Bankruptcy Institute Journal, vol. 21(8), pp. 20 and 38 (2002). 
Goodman, Joshua, and Adam Levitin, "Bankruptcy Law and the Cost of Credit: The Impact of Cramdown on Mortgage Interest Rates,” working paper, Kennedy School of Government, Harvard University, August 2012.

Gropp, Reint, J. Karl Scholz, and Michelle J. White, "Personal Bankruptcy and Credit Supply and Demand," Quarterly Journal of Economics, vol. 112, pp. 217-251, Feb. 1997.

Hockett, Robert, "Paying Paul and Robbing No One: An Eminent Domain Solution for Underwater Mortgage Debt," Federal Reserve Bank of New York, Current Issues in Economics and Finance, Vol. 19:5, 2013, www.newyorkfed.org/research/current issues.

Jappelli, Tullio, Marco Pagano, and Magda Bianco. "Courts and Banks: Effects of Judicial Enforcement on Credit Markets." Journal of Money, Credit and Banking, vol. 37:2, pp. 223-44, 2005.

Keys, B., T. Mukherjee, A. Seru, and V. Vig. "Did Securitization Lead to Lax Screening? Evidence from Subprime Loans,” Quarterly Journal of Economics. 2009.

Kau, J.B., and T. Kim, "Waiting to Default: The Value of Delay," J. of the Am. Real Estate and Urban Economics Association,” vol. 22:3, pp. 539-551 (1994).

Kittle, David, "Statement before the Subcommittee on Commercial and Administrative Law of the H. Comm. on the Judiciary," $110^{\text {th }}$ Cong. at 3 (2007).

Kuchler, Theresa, and Johannes Stroebel, "Foreclosure and Bankruptcy: Policy Conclusions from the Current Crisis," working paper, Stanford University, April 2009.

Laeven, Luc, and Giovanni Majnoni. "Does Judicial Efficiency Lower the Cost of Credit?" Journal of Banking \& Finance 29, no. 7 (2005): 1791-1812.

La Porta, Rafael, Florencio Lopez-de-Silanes, Andrei Shleifer, and Robert W. Vishny. "Legal determinants of external finance." The Journal of Finance 52, no. 3 (1997): 1131-1150.

Levitin, Adam, "Resolving the Foreclosure Crisis: Modification of Mortgages in Bankruptcy," Wisconsin Law Review, vol. 2009:1, pp. 565-656.

Li, Wenli, Michelle J. White, and Ning Zhu, "Did Bankruptcy Reform Cause Mortgage Defaults to Rise?" American Economic Journal: Economic Policy, vol. 3, pp. 123-147 (2011).

Lin, Emily Y., and Michelle J. White, "Bankruptcy and the Market for Mortgage and Home Improvement Loans," Journal of Urban Economics, vol. 50:1, pp. 138-162, July 2001.

Pence, Karen, "Foreclosing on Opportunity: State Laws and Mortgage Credit," Review of Economics and Statistics, vol. 88(1), pp. 177-182, 2006. 
Stiglitz, Joseph, and Andrew Weiss, "Credit Rationing in Markets with Imperfect Information," American Economic Review, vol. 71:3, pp. 393-410, 1981.

Stolberg, S., and E.L. Andrews, “\$275 Billion Plan Seeks to Address Crisis In Housing," New York Times, Feb. 18, 2009.

Visaria, Sujata. "Legal Reform and Loan Repayment: The Microeconomic Impact of Debt Recovery Tribunals in India." American Economic Journal: Applied Microeconomics, vol. ?: pp. 59-81 (2009).

White, A.M., "Deleveraging the American Homeowner: The Failure of 2008 Voluntary Mortgage Contract Modifications," Connecticut Law Review (2009).

White, Michelle J., "Economics of Corporate and Personal Bankruptcy Law." In The New Palgrave Dictionary of Economics, 2nd edition, 2008.

White, Michelle J., and Ning Zhu, "Saving Your Home in Chapter 13 Bankruptcy," Journal of Legal Studies, vol. 39:1, pp. 33-61, January 2010.

Winn, Jane Kauffman, “Lien-Stripping After Nobelman," Loyola of Los Angeles Law Review, vol 27, p. 541, 1993-94. 


\section{Appendix Table 1: \\ Summary Statistics for Circuit Court Samples \\ HMDA}

\begin{tabular}{|l|c|c|c|}
\hline & Circuit 10 & Circuit 2 & Circuit 5 \\
\hline Approval rate & $0.756(0.429)$ & $0.797(0.409)$ & $0.816(0.388)$ \\
\hline Mortgage loan size (\$) & $84,700(66,700)$ & $85,400(64,000)$ & $89,185(63,557)$ \\
\hline $\begin{array}{l}\text { If African-American } \\
\text { applicant }\end{array}$ & $0.0430(.203)$ & $0.0382(0.191)$ & $0.0371(0.189)$ \\
\hline $\begin{array}{l}\text { If other non-white } \\
\text { applicant }\end{array}$ & $0.0601(0.238)$ & $0.0493(0.217)$ & $0.0471(0.2119)$ \\
\hline If female applicant & $0.155(0.362)$ & $0.147(0.354)$ & $0.149(0.356)$ \\
\hline If married applicant & $0.739(0.439)$ & $0.763(0.425)$ & $0.761(0.426)$ \\
\hline Income (\$) & $61,100(50,000)$ & $62,700(49,100)$ & $62,055(46,193)$ \\
\hline $\begin{array}{l}\text { If refinance (versus } \\
\text { purchase) }\end{array}$ & $0.362(0.481)$ & $0.583(0.493)$ & $0.566(0.496)$ \\
\hline $\begin{array}{l}\text { Lagged unemployment } \\
\text { rate }(\%, \text { MSA) }\end{array}$ & $6.49(1.87)$ & $7.72(2.12)$ & $7.28(2.02)$ \\
\hline Income (\$) (MSA) & $38,100(6,780)$ & $39,700(7,140)$ & $41,053(7,641)$ \\
\hline $\begin{array}{l}\text { Lagged house price } \\
\text { growth rate (MSA) }\end{array}$ & $-0.00232(.0111)$ & $0.00300(0.00759)$ & $0.00221(0.00693)$ \\
\hline $\begin{array}{l}\text { Chapter 13 filing rate } \\
\text { (district) }\end{array}$ & $0.136(.343)$ & $0.185(0.388)$ & $0.150(0.357)$ \\
\hline $\begin{array}{l}\text { If minority percent }> \\
\text { 30 (census tract) }\end{array}$ & $0.157(.364)$ & $0.138(0.345)$ & $0.124(0.329)$ \\
\hline
\end{tabular}




\section{MIRS}

\begin{tabular}{|c|c|c|c|c|c|}
\hline & Circuit 9 & Circuit 3 & Circuit 10 & Circuit 2 & Circuit 5 \\
\hline $\begin{array}{l}\text { Loan size, if } \\
\text { approved }(\$)\end{array}$ & $\begin{array}{l}103,769 \\
(63475) \\
\end{array}$ & $\begin{array}{c}86,552 \\
(52561) \\
\end{array}$ & $\begin{array}{r}87753 \\
(51273) \\
\end{array}$ & $\begin{array}{c}95773 \\
(57964) \\
\end{array}$ & $\begin{array}{c}94052 \\
(57278)\end{array}$ \\
\hline $\begin{array}{l}\text { Interest rate } \\
\text { (percent) }\end{array}$ & $\begin{array}{l}10.16 \\
(.778) \\
\end{array}$ & $\begin{array}{l}10.10 \\
(.754) \\
\end{array}$ & $\begin{array}{c}9.89 \\
(.873) \\
\end{array}$ & $\begin{array}{c}8.50 \\
(.995) \\
\end{array}$ & $\begin{array}{c}8.09 \\
(1.03) \\
\end{array}$ \\
\hline $\begin{array}{l}\text { Lagged } \\
\text { unemployment } \\
\text { rate }(\%, \mathrm{MSA})\end{array}$ & $\begin{array}{c}5.03 \\
(1.74)\end{array}$ & $\begin{array}{l}5.39 \\
(1.95)\end{array}$ & $\begin{array}{l}6.20 \\
(2.33)\end{array}$ & $\begin{array}{c}6.79 \\
(2.35)\end{array}$ & $\begin{array}{c}6.51 \\
(2.32)\end{array}$ \\
\hline $\begin{array}{l}\text { Income (\$) } \\
(\mathrm{MSA})\end{array}$ & $\begin{array}{l}37,800 \\
(6,840)\end{array}$ & $\begin{array}{l}35,400 \\
(6,850)\end{array}$ & $\begin{array}{l}35,900 \\
(6,540)\end{array}$ & $\begin{array}{l}39,900 \\
(7,280)\end{array}$ & $\begin{array}{l}39,700 \\
(7,220)\end{array}$ \\
\hline $\begin{array}{l}\text { Lagged house } \\
\text { price growth } \\
\text { rate (MSA) }\end{array}$ & $\begin{array}{c}.0065539 \\
(.0091351)\end{array}$ & $\begin{array}{c}.0020195 \\
(.0090266)\end{array}$ & $\begin{array}{l}-0.00397 \\
(.00925)\end{array}$ & $\begin{array}{c}.00296 \\
(.00817)\end{array}$ & $\begin{array}{c}0.00327 \\
(0.00731)\end{array}$ \\
\hline $\begin{array}{l}\text { Chapter } 13 \\
\text { filing rate } \\
\text { (district) }\end{array}$ & $\begin{array}{l}0.197 \\
(.398)\end{array}$ & $\begin{array}{l}0.167 \\
(.373)\end{array}$ & $\begin{array}{l}0.177 \\
(.382)\end{array}$ & $\begin{array}{l}0.165 \\
(.371)\end{array}$ & $\begin{array}{l}0.232 \\
(.422)\end{array}$ \\
\hline
\end{tabular}




\section{Appendix Table 2: \\ Effects of the Circuit Court Decision to Abolish Strip-down}

HMDA: Approval Rates

\begin{tabular}{|c|c|c|c|}
\hline & Circuit 10 & Circuit 2 & Circuit 5 \\
\hline Circuit*Post & $-0.0132(.454)$ & $.0025(.873)$ & $-0.0077(.324)$ \\
\hline $\begin{array}{l}\text { If Chapter } 13 \\
\text { filing rate is in } \\
\text { the highest decile }\end{array}$ & $0.0123(.463)$ & $-0.0160(.000)$ & $-0.0189 * * *(.000)$ \\
\hline $\begin{array}{l}\text { If African- } \\
\text { American }\end{array}$ & $-0.132 * * *(.000)$ & $-.1368 * * *(.000)$ & $-0.126 * * *(.000)$ \\
\hline If other non-white & $-0.0600(.000)$ & $-0.0501 * * *(.000)$ & $-0.0433 * * *(.000)$ \\
\hline If female & $-0.00025(.952)$ & $.0114 * * *(.000)$ & $0.0106 * * *(.000)$ \\
\hline If married & $0.049 * * *(.000)$ & $0.049 * * *(.000)$ & $0.048 * * *(.000)$ \\
\hline Income & $0.00043 * * *(.000)$ & $0.00043 * * *(.000)$ & $0.00051 * * *(.000)$ \\
\hline $\begin{array}{l}\text { If refinance } \\
\text { (versus purchase) }\end{array}$ & $0.0110 * * *(.463)$ & $0.0100(.302)$ & $0.0209 * * *(.000)$ \\
\hline $\begin{array}{l}\text { If minority } \\
\text { percent > } 30\end{array}$ & $-0.0702 * * *(.000)$ & $-0.0639 * * *(.000)$ & $-0.0629 * * *(.000)$ \\
\hline $\begin{array}{l}\text { Unemployment } \\
\text { rate (lagged) }\end{array}$ & $0.0007(.617)$ & $-0.0007(.420)$ & $0.0003(.612)$ \\
\hline MSA income (\$) & $0.000586(.457)$ & $0.0035 * * *(.000)$ & $0.0033 * * *(.000)$ \\
\hline $\begin{array}{l}\text { Monthly house } \\
\text { price growth rate }\end{array}$ & $0.000075(.405)$ & $0.000027(0.576)$ & $0.00000(.940)$ \\
\hline District dummies & $\mathrm{Y}$ & $\mathrm{Y}$ & $Y$ \\
\hline $\begin{array}{l}\text { District-level time } \\
\text { trends }\end{array}$ & $\mathrm{Y}$ & $\mathrm{Y}$ & $\mathrm{Y}$ \\
\hline Month dummies & $\mathrm{Y}$ & $\mathrm{Y}$ & $\mathrm{Y}$ \\
\hline Sample size & 88,442 & 207,860 & 269,514 \\
\hline R-squared & .0367 & .0417 & .046 \\
\hline
\end{tabular}

Notes: For each regression, the sample period is three months before to three months after the relevant court decision. P-values are in the parenthesis. 
HMDA: Mortgage Loan Size

\begin{tabular}{|c|c|c|c|}
\hline & Circuit 10 & Circuit 2 & Circuit 5 \\
\hline Circuit*Post & $-2.016(.573)$ & $0.4927(.754)$ & $1.029(.739)$ \\
\hline $\begin{array}{l}\text { If Chapter } 13 \\
\text { filing rate is in } \\
\text { the highest decile }\end{array}$ & $2.686(.446)$ & $-2.503 *(.083)$ & $-1.995 * * *(.000)$ \\
\hline $\begin{array}{l}\text { If African- } \\
\text { American }\end{array}$ & $-21.687 * * *(.000)$ & $-20.782 * * *(.000)$ & $-20.356 * * *(.000)$ \\
\hline If other non-white & $-8.940 * * *(.000)$ & $-5.055 * * *(.000)$ & $-5.024 * * *(.000)$ \\
\hline If female & $-4.663 * * *(.000)$ & $-3.560 * * *(.000)$ & $-3.786 * * *(.000)$ \\
\hline If married & $12.049 * * *(.000)$ & $10.170 * * *(.000)$ & $10.821 * * *(.000)$ \\
\hline Income & $0.627 * * *(.000)$ & $0.658 * * *(.000)$ & $0.707 * * *(.000)$ \\
\hline $\begin{array}{l}\text { If refinance } \\
\text { (versus purchase) }\end{array}$ & $-10.735 * * *(.000)$ & $--9.154 * * *(.000)$ & $-8.376 * * *(.000)$ \\
\hline $\begin{array}{l}\text { If minority } \\
\text { percent > } 30\end{array}$ & $-11.168 * * *(.000)$ & $-15.297 * * *(.000)$ & $-16.538 * * *(.000)$ \\
\hline $\begin{array}{l}\text { Unemployment } \\
\text { rate (lagged) }\end{array}$ & $-0.039(.870)$ & $-0.206(.336)$ & $0.121(.473)$ \\
\hline MSA income (\$) & $1.069 * * *(.001)$ & $2.016^{* * *}(.000)$ & $2.462 * * *(.000)$ \\
\hline $\begin{array}{l}\text { Monthly house } \\
\text { price growth rate }\end{array}$ & $0.0147(.160)$ & $0.0014(0.149)$ & $0.0044(.693)$ \\
\hline Constant & $-11.405(.298)$ & $-56.255 * * *(.000)$ & $-61.669 * * *(.000)$ \\
\hline District dummies & $\mathrm{Y}$ & $\mathrm{Y}$ & $\mathrm{Y}$ \\
\hline $\begin{array}{l}\text { District-level time } \\
\text { trends }\end{array}$ & $\mathrm{Y}$ & $\mathrm{Y}$ & $\mathrm{Y}$ \\
\hline Month dummies & $\mathrm{Y}$ & $\mathrm{Y}$ & $\mathrm{Y}$ \\
\hline Sample size & 88,442 & 207,860 & 269,514 \\
\hline R-squared & .0256 & .030 & .035 \\
\hline
\end{tabular}


MIRS: Interest Rates

\begin{tabular}{|l|c|c|c|c|c|}
\hline & Circuit 2 & Circuit 10 & Circuit 9 & Circuit 3 & Circuit 5 \\
\hline Circuit*Post & $0.109(.37)$ & $-0.052(.76)$ & $0.146^{* *}(.04)$ & $-0.271^{*}(.08)$ & $-0.0425(.71)$ \\
\hline $\begin{array}{l}\text { Monthly house } \\
\text { price growth rate }\end{array}$ & $0.412(.90)$ & $1.01(.51)$ & $-0.796(.41)$ & $-4.33^{*}(.07)$ & $3.31(.51)$ \\
$\begin{array}{l}\text { Unemployment } \\
\text { rate (lagged) }\end{array}$ & $0.0238(.33)$ & $0.0479^{*}(.06)$ & $0.0112(.17)$ & $0.031(.15)$ & $0.0149(.49)$ \\
\hline MSA income (\$) & $-7.06 \mathrm{e}-6(.51)$ & $-1.14 \mathrm{e}-5(.16)$ & $\begin{array}{c}-8.47 \mathrm{e}^{*} 6^{* *} \\
(.02)\end{array}$ & $\begin{array}{c}-2.07 \mathrm{e}-5^{* * *} \\
(.00)\end{array}$ & $-4.41 \mathrm{e}-6(.42)$ \\
\hline $\begin{array}{l}\text { If Chapter 13 filing } \\
\text { rate is in the } \\
\text { highest decile }\end{array}$ & $-0.350^{* *}(.03)$ & $0.06(.45)$ & & $-0.0559(.46)$ & $0.0586(.15)$ \\
\hline District dummies & Yes & Yes & Yes & Yes & Yes \\
\hline $\begin{array}{l}\text { District level } \\
\text { linear time trends }\end{array}$ & Yes & Yes & Yes & Yes & Yes \\
\hline Month dummies & Yes & Yes & Yes & Yes & Yes \\
\hline Sample size & 18,747 & 8,929 & 31,271 & 12,109 & 24,159 \\
\hline R-squared & .128 & .146 & .077 & .127 & .173 \\
\hline
\end{tabular}

MIRS: Mortgage Loan Size

\begin{tabular}{|c|c|c|c|c|c|}
\hline & Circuit 2 & Circuit 10 & Circuit 9 & Circuit 3 & Circuit 5 \\
\hline Circuit ${ }^{*}$ Post & $1,159(.78)$ & $3,680(.75)$ & $4,680(.23)$ & $9,440(.36)$ & $5,530(.32)$ \\
\hline $\begin{array}{l}\text { Monthly house } \\
\text { price growth rate }\end{array}$ & $\begin{array}{l}219,000^{*} \\
(.06)\end{array}$ & $\begin{array}{c}-133,000^{*} \\
(.07)\end{array}$ & $\begin{array}{c}-147,000 \\
(.35)\end{array}$ & $\begin{array}{c}97,000 \\
(.36)\end{array}$ & $11,300(.90)$ \\
\hline $\begin{array}{l}\text { Unemployment } \\
\text { rate (lagged) }\end{array}$ & $\begin{array}{c}-2,580^{*} \\
(.09)\end{array}$ & $\begin{array}{c}3,220^{* * *} \\
(.00)\end{array}$ & $\begin{array}{c}-2,440^{* * * *} \\
(.00)\end{array}$ & $\begin{array}{c}-3,410^{* * *} \\
(.00)\end{array}$ & $-1,290(.35)$ \\
\hline MSA income (\$) & $\begin{array}{l}1.62^{* * * *} \\
(.00)\end{array}$ & $\begin{array}{c}-1.92^{* * *} \\
(.00)\end{array}$ & $\begin{array}{l}2,31^{* * *} \\
(.00)\end{array}$ & $\begin{array}{c}2.38^{* * *} \\
(.00)\end{array}$ & $\begin{array}{l}1.97^{* * *} \\
(.00)\end{array}$ \\
\hline $\begin{array}{l}\text { If Chapter } 13 \text { filing } \\
\text { rate is in the } \\
\text { highest decile }\end{array}$ & $\begin{array}{c}-10,100^{* * *} \\
(.00)\end{array}$ & $\begin{array}{c}5,470 \\
(.14)\end{array}$ & & $\begin{array}{l}9,170 \\
(.16)\end{array}$ & $\begin{array}{c}-8,710^{*} \\
(.07)\end{array}$ \\
\hline District dummies & Yes & Yes & Yes & Yes & Yes \\
\hline $\begin{array}{l}\text { District level } \\
\text { linear time trends }\end{array}$ & Yes & Yes & Yes & Yes & Yes \\
\hline Month dummies & Yes & Yes & Yes & Yes & Yes \\
\hline Sample size & 18,747 & 8,929 & 31,271 & 12,109 & 24,159 \\
\hline R-squared & .221 & .167 & .34 & .197 & .189 \\
\hline
\end{tabular}

Notes: For each regression, the sample period is three months before to three months after the relevant court decision. $p$-values are in parenthesis. $* * *, * *$ and $*$ indicate statistical significance at the $1 \%, 5 \%$, and $10 \%$ levels, respectively. 